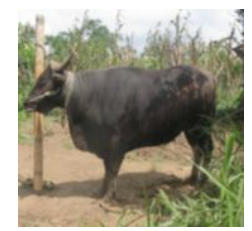

Jurmal FADET UNUD

\title{
SIFAT FISIK DAN KANDUNGAN SERAT KASAR SILASE BATANG PISANG DISUPLEMENTASI BERBAGAI LEVEL HIJAUAN KEMBANG TELANG (Clitoria ternatea)
}

\author{
Deswanto., I. W. Suarna dan N. N. Suryani \\ PS Sarjana Peternakan, Fakultas Peternakan, Universitas Udayana, Denpasar, Bali \\ E-mail: deswanto@student.unud.ac.id, No Hp: +6282339352301
}

\begin{abstract}
ABSTRAK
Penelitian ini bertujuan untuk mengetahui level penambahan hijauan kembang telang (Clitoria ternatea) pada silase batang pisang ditinjau dari sifat fisik dan kandungan serat kasar. Pembuatan silase dilakukan di Stasiun riset Sesetan Fakultas Peternakan Universitas Udayana, Denpasar. Analisis sifat fisik dan kandungan serat kasar dilakukan di Laboratorium Nutrisi dan Makanan Ternak Fakultas Peternakan Universitas Udayana. Penelitian ini mengunakan Rancangan Acak Lengkap (RAL) terdiri dari 4 perlakuan dan 4 ulangan. Perlakuan A: $65 \%$ batang pisang $+30 \%$ pollar $+5 \%$ (molasis + EM4), B: $55 \%$ batang pisang $+10 \%$ C. ternatea $+30 \%$ pollar $+5 \%$ (molasis + EM4), perlakuan C: $45 \%$ batang pisang + $20 \%$ C. ternatea $+30 \%$ pollar $+5 \%$ (molasis + EM4), dan perlakuan D: $35 \%$ batang pisang + $30 \%$ C. ternatea $+30 \%$ pollar $+5 \%$ (molasis + EM4). Variabel yang diamati adalah densitas, daya serap air, daya larut air dan kandungan serat kasar.Hasil penelitian menujukkan densitas nyata $(\mathrm{P}<0,05)$ lebih tinggi pada perlakuan $\mathrm{D}$ yaitu $0,17 \mathrm{~g} / \mathrm{mldibandingkan}$ perlakuan $\mathrm{A}, \mathrm{B}$ dan C. Daya larut air nyata $(\mathrm{P}<0,05)$ lebih tinggi pada perlakuan Dyaitu $48,38 \%$ dibandingkan perlakuan A, B dan C.Daya serap air nyata $(\mathrm{P}<0,05)$ lebih tinggi pada perlakuan A yaitu232,26\% dibandingkan perlakuan B, C dan D. Kandungan serat kasar tidak menujukkan perbedaan yang nyata diantara semua perlakuan. Berdasarkan hasil penelitian ini, dapat disimpulkan bahwa silase batang pisang disuplementasi 10-30\% hijauan kembang telang (Clitoria ternatea) dapat meningkatkan densitas, daya larut air dan menurunkan daya serap air dan kandungan serat kasar. Belum diperoleh level penambahan Citoria ternatea yang optimal.
\end{abstract}

Kata kunci: silase, batang pisang, kembang telang, sifat fisik, kandungan serat.

\section{PHYSICAL FEATURES AND CRUDE FIBER CONTENT OF BANANA STEM SILAGE SUPPLEMENTED BY VARIOUS LEVELS OF KEMBANG TELANG (Clitoria ternatea)}

\begin{abstract}
This study aims to determine the level of addition of forage (Clitoria ternatea) on banana stem silage in terms of physical features and crude fiber content. Silage was made at the Farm of Sesetan Faculty of Animal Husbandry, Udayana University, Jl. Raya Sesetan, Gang Markisa, Denpasar. Analysis of physical features and crude fiber content was conducted at the Laboratory of Animal Nutrition and Tropical Forage Science Faculty of Animal Husbandry Udayana University. The methot used a Completely Randomized Design (CRD) was used consisting of 4 treatments and 4 replications. Treatment A: $65 \%$ banana stem $+30 \%$ pollar +
\end{abstract}


$5 \%$ (molasis + EM4), teratment B: $55 \%$ banana stem $+10 \%$ C. ternatea $+30 \%$ pollar $+5 \%$ (molasis + EM4), treatment C: $45 \%$ stem banana $+20 \%$ C. ternatea $+30 \%$ pollar $+5 \%$ (molasis + EM4), and treatment D: $35 \%$ banana stem $+30 \%$ C. ternatea $+30 \%$ pollar $+5 \%$ (molasis + EM4). The observed variables were that density, water absorption, water solubility and crude fiber content were as ovserved variables. The results showed that the real density $(\mathrm{P}<0.05)$ was higher in treatment $\mathrm{D}$ that was $0.17 \mathrm{~g} / \mathrm{ml}$ compared to treatments $\mathrm{A}, \mathrm{B}$ and $\mathrm{C}$. The water solubility significantly $(\mathrm{P}<0.05)$ was higher in treatment $\mathrm{D}$ which was $48,38 \%$ compared to treatments $\mathrm{A}, \mathrm{B}$ and $\mathrm{C}$. The apparent water absorption $(\mathrm{P}<0.05)$ was higher in treatment $\mathrm{A}$ that was $232.26 \%$ compared to treatments B, C and D. The crude fiber content does not show a real different among all treatments.Based on the results of this study, it can be concluded that banana stem silage supplemented by $10-30 \%$ of forage flower (Clitoria ternatea) can increase density, water solubility and reduce water absorption and crude fiber content. For the optimal level supplementation of Clitoria ternatea that could improve the quality of banana stem silage not yet obtained.

Key Words: silage, banana stems, kembang telang, physical properties, fiber content.

\section{PENDAHULUAN}

Hijauan pakan ternak yang tersedia dalam jumlah yang cukup dengan kualitas baik merupakan hal pokok dalam mengembangkan usaha peternakan, khususnya ternak ruminansia. Pada musim penghujan ketersedian hijauan sangat melimpah, pada musim kemarau ketersediaan hijauan sangat terbatas sehingga untuk mengatasi hal tesebut diperlukan teknologi pengawetan hijauan berupa pembuatan silase dengan memanfaatkan limbah perkebunanyang memiliki potensi diantaranya dengan memanfaatkan batang pisang.

Batang pisang merupakan salah satu limbah pertanian atau perkebunan yang dihasilkan dari tanaman pisang yang telah dipanen dapat dijadikan sebagai bahan pakan alternatif (Advena, 2014).Nilai gizi batang pisang adalah bahan kering $8,62 \%$, abu $24,31 \%$, protein kasar $4,81 \%$, serat kasar 27,73\%, lemak kasar 2,75\%, bahan ekstrak tanpa nitrogen (BETN) 40,61\%, hemiselulosa 20,34\%, selulosa 26,64\% dan lignin 9,92\% (Hasrida, 2011).

Pengolahan pada batang pisang bertujuan untuk meningkatkan kandungan gizi, kecernaan, dan palatabilitasnya. Pengolahan batang pisang juga akan memperlama daya simpannya sebagai pakan, diantaranya adalah amoniasi, dan fermentasi (Advena, 2014).

Tanaman Clitoria ternatea berasal dari Amerika Selatan bagian tengah yang menyebar ke daerah tropik sejak abad ke 19, terutama ke Asia Tenggara termasuk Indonesia. Tanaman ini tumbuh subur di bawah sinar matahari penuh, tetapi dapattumbuh di bawah naungan seperti di perkebunan karet dan kelapa. Potensi Clitoria ternatea sebagai pakan yang baik karena memiliki nilai nutrisi yang tinggi dan juga sangat disukai ternak (Suarna, 2005). Kalamani dan Gomez (2001) melaporkan bahwa protein kasar tanaman berkisar 14-20\%, sedangkan 
kadar protein kasar dan serat kasar dalam daun masing-masing adalah 21,5 dan 29\%, sedangkan pada biji mengandung $25-38 \%$ protein, gula total $5 \%$ dan lemak $10 \%$.

Kualitas suatu bahan pakan penyusun ransum ternak dapat dinilai dengan melakukan pengujian bahan pakan. Pengujian bahan pakan penyusun ransum dapat dilakukan dengan pengujian komposisi sifat fisik (seperti: densitas, daya serap air dan daya larut air serta serat kasar).

Sifat fisik bahan penyusun ransum merupakan salah satu indikator untuk mengetahui kualitas pakan. Sifat fisik pakan juga merupakan salah satu hal yang mempengaruhi cara makan dari ternak ruminansia. Pakan yang baik secara morfologi permukaanya tidak kasar, bau tidak tengik, dan tidak busuk atau berjamur. Densitas ransum mengindikasikan keambaan, semakin rendah densitas suatu pakan, maka makin amba pakan tersebut (Suryani et al., 2015). Dengan memperhatikan kondisi dari fisik pakan ini secara tidak langsung juga memperhatikan kualitas dari pakan yang akan diberikan kepada ternak.

Beberapa penelitian silase batang pisang dan berbagai tambahan bahan lain sudah dilakukan oleh Santi et al.(2012), yang melakukan penelitian untuk mengetahui kualitas dan nilai kecernaan in vitro silase batang pisang dengan penambahan beberapa akselerator dengan hasil penambahan molases sebanyak $10 \%$ menghasilkan silase batang pisang yang dikategorikan berkualitas baik dilihat darisegi karakteristik fisik, kimiawi maupun nilai kecernaan in vitro dan lama ensilase optimal untuk membuat silase batang pisang yaitu 21 hari. Keberhasilan proses fermentasi anaerob (ensilase), diantaranya dipengaruhi oleh kandungan karbohidrat terlarut dan pengembangan kecocokan seperti penambahan bahan aditif, diantaranya kelompok gula yaitu molasses (Bolsen, 1993). Fermentasi batang pisang dengan probiotik yang terbaik terjadi pada lama inkubasi 18 hari, dengan kandungan bahan kering 52,18\%, protein kasar 12,18\% dan serat kasar 20,25\%. Starbio dan Probiofeed dapat digunakan sebagai starter fermentasi pada batang pisang untuk pakan ruminansia (Advena, 2014).

Penelitian mengenai batang pisang juga dilakukan Dhalika et al. (2011) dengan menggunakan campuran batang pisang, umbi singkong dan biji jagung yang difermentasi secara anaerob (ensilase).

Sampai saat ini pembuatan silase batang pisang yang ditambahkan Clitoria ternatea, belum ada informasi. Penelitian ini bertujuan untuk mencari kualitas sifat fisik silase batang pisang yang ditambahkan Clitoria ternatea. 


\section{MATERI DAN METODE}

\section{Alat dan bahan}

Alat yang digunakan digunakan dalam membuat silase ini adalah plastik besar untuk membungkus silase selama penyimpanan, alas pemotong (talenan) dan pisau untuk memotong batang pisang dan Clitoria ternatea. Bahan yang digunakan pada penelitian ini adalah batang pisang sebagai bahan utama, Clitori ternatea sebagai tambahan perlakuan, molasses, EM4, dan pollard sebagai tambahan untuk keberasilan silase.

Alat-alat yang digunakan dalam penentuan densitas dipergunakan alat penggiling dengan diameter $1 \mathrm{~mm}$, timbangan analitik dan tabung silinder ukuran $37 \mathrm{ml}$. Penentuan daya serap air dipergunakan cawan porselin, timbangan analitik, kertas saring, dan pompa vacum. dan penentuan daya larut air dipergunakan oven $105^{\circ} \mathrm{C}$ dan timbangan analitik.Dalam analisis kandungan serat kasar (SK) dipergunakan alat gelas piala, cawan porselin, kertas saring, corong buchner, kondensor, penangas pasir, dan pompa vakum. Penentuan kadar serat kasar (SK) memerlukan zat kimia $\mathrm{H}_{2} \mathrm{SO}_{4}$ 0,3 N, $\mathrm{NaOH} 1,5 \mathrm{~N}$, alkohol dan Aceton.

\section{Tempat dan waktu}

Penelitian ini dilakukan pada bulan Juni sampai bulan September 2019. Pembuatan silase di Farm Sesetan Fakultas Peternakan Universitas Udayana Jl. Sesetan, Gg. Mariksa Denpasar. Analisis densitas, daya serap air, daya larut air dan kandungan serat kasar di Laboratorium Nutrisi dan Makanan Ternak Fakultas Peternakan Uiniversitas Udayana.

\section{Rancangan Percobaan}

Rancangan digunakan pada penelitian ini mengunakan Rancangan Acak Lengkap (RAL) terdiri dari 4 perlakuan dan 4 ulangan :
A: $65 \%$ batang pisang $+30 \%$ pollar $+5 \%$ (molasis + EM4 $)$
B: $55 \%$ batang pisang $+10 \%$ C. ternatea $+30 \%$ pollar $+5 \%$ (molasis + EM4)
C: $45 \%$ batang pisang $+20 \%$ C. ternatea $+30 \%$ pollar $+5 \%$ (molasis + EM4)
D: $35 \%$ batang pisang $+30 \%$ C. ternatea $+30 \%$ pollar $+5 \%$ (molasis + EM 4$)$.

\section{Pembuatan silase}

Cara pembuatan silase ini, antara lain; 1) batang pisang dipotong-potong dengan ukuran 4-5 cm. Batang pisang selanjutnya dilayukan selama 1-2 hari; 2) setelah batang pisang dilayukan selanjutnya batang pisang ditimbang dan dicampur sesuai dengan perlakuannya serta 4 ulangannya; 3) campurkan sehomogen mungkin, kemudian masukan ke dalam kantong plastik;4) simpan dalam kedap udara (anaerob) selama 21 hari; 5) cari sifat fisik (densitas, daya serap air, daya larut air, kandungan serat kasar) 


\section{Peubah yang diamati}

Sifat fisik bahan penyusun ransum adalah salah satu indikator untuk mengetahui kualitas pakan (densitas, daya serap air, daya larut air dan serat kasar).

\section{Densitas}

Sampel silase yang telah digiling halus dimasukan ke dalam tabung silinder ukuran $37 \mathrm{ml}$ sampai permukaan rata dan selanjutnya ditimbang.

Densitas $=\frac{\text { berat sempel }(\mathrm{g})}{\text { Volume tabung }(\mathrm{ml})}$

\section{Daya Serap Air}

Sampel silase yang sudah kering udara (dioven dengan tempertatur $60^{\circ} \mathrm{C}$ ) yang telah digiling halus dan dimasukkan ke dalam tabung sebanyak 3 gram diberi air sebanyak 25 ml. kemudian sempel tersebut direndam air 1 x 24 jam. Setelah direndam, sempel disaring dengan kertas saring dan disedot dengan menggunakan pompa vakum sampai airnya tidak menetes. Lalu sempel ditimbang untuk diproleh air.

Daya serap air $=\frac{\text { (berat akhir-berat kertas saring)-berat sempel awal) }}{\text { berat sampel awal }} \times 100 \%$

\section{Daya Larut Air}

Sampel silase kering udara (dioven dengan temperature $60^{\circ} \mathrm{C}$ ) yang telah digiling halus dan disaring dengan diameter saringan $1 \mathrm{~mm}$ dimasukkan kedalam cawan sebanyak 3 gram. Kemudian sempel direndam selama 1 x 24 jam. Setelah direndam, sampel disaring dengan kertas saring kemudian disedot dengan pompa vakum sampai airnya tidak menetes, selanjutnya sampel dioven pada suhu $105^{\circ} \mathrm{C}$ selama $2 \mathrm{jam}$, kemudian ditimbang.

Daya larut air $=\frac{\text { berat bahan kering awal-(berat akhir-berat kertas garing) }}{\text { berat bahan kering awal }} \times 100 \%$

\section{Serat Kasar}

Berikut adalah prosedur kerja dari analisis serat kasar menurut AOAC (Association of Analytical Communities) (1992). Sampel sebanyak $1 \mathrm{~g}$ di masukkan ke dalam gelas piala tinggi $600 \mathrm{ml}$. Ditambahkan $50 \mathrm{ml} \mathrm{H}_{2} \mathrm{SO}_{4}$ 0,3 N. Dididihkan selama 30 menit diatas hot plate. $25 \mathrm{ml} \mathrm{NaOH}$ 1,5 N dimasukkan dan didihkan selama 30 menit. Kertas saring bebas abu yang telah dikeringkan disiapkan bersama cawan porselin dalam oven $105-110^{\circ} \mathrm{C}$, catat beratnya. Saring dengan bantuan pompa vakum. Lalu cuci berturut-turut dengan: aquadest panas $50 \mathrm{ml}, \mathrm{H}_{2} \mathrm{SO}_{4}$ 0,3 N $50 \mathrm{ml}$, alkohol $25 \mathrm{ml}$ dan 
aceton $25 \mathrm{ml}$. Kertas saring yang berisi residu dipindahkan ke dalam cawan porselin. Keringkan dalam oven $105-110^{\circ} \mathrm{C}$ selama $1-3$ jam, timbang.

Serat kasar $=\frac{c-d-b}{a} \times 100 \%$

Keterangan :

a. Berat sampel

b. Berat cawan + kertas saring

c. Berat cawan + kertas saring + residu kering

d. Berat cawan + residu abu

Hasil analisis kecernan bahan kering dan bahan organik secara in-vitro serta kandungan BETN dan TDN dari silase batang pisang dengan berbagai level Clitora ternatea (Dewi, et al., 2020) disajikan pada Tabel 1.

Tabel 1. Kecernaan silase batang pisang dengan berbagai level Clitoria ternatea secara in vitro

\begin{tabular}{lccccc}
\hline \multirow{2}{*}{ Parameter } & \multicolumn{4}{c}{ Perlakuan } & \multirow{2}{*}{ SEM } \\
\cline { 2 - 4 } & $\mathrm{A}$ & $\mathrm{B}$ & $\mathrm{C}$ & $\mathrm{D}$ & \\
\hline Kecernaan BK (\%) & $58,25^{\mathrm{a}}$ & $62,25^{\mathrm{ba}}$ & $68,64^{\mathrm{c}}$ & $70,40^{\mathrm{c}}$ & 2,70 \\
Kecernaan BO (\%) & $60,95^{\mathrm{a}}$ & $69,82^{\mathrm{b}}$ & $71,53^{\mathrm{bc}}$ & $73,08^{\mathrm{c}}$ & 2,76 \\
BETN(\%) & $33,59^{\mathrm{a}}$ & $35,99^{\mathrm{a}}$ & $36,95^{\mathrm{a}}$ & $38,39^{\mathrm{a}}$ & 1,81 \\
TDN(\%) & $73,97^{\mathrm{a}}$ & $73,92^{\mathrm{a}}$ & $75,15^{\mathrm{a}}$ & $78,58^{\mathrm{a}}$ & 3,24 \\
\hline
\end{tabular}

Sumber: Dewi., et al. (2020)

\section{Analisis data}

Data yang diperoleh dianalisis dengan sidik ragam, dan apabila nilai rata-rata pada perlakuan yang berbeda nyata $(\mathrm{P}<0,05)$ dilakukan uji BNT (Steel dan Torrie, 1989).

\section{HASIL DAN PEMBAHASAN}

\section{Sifat Fisik dan Kandungan Serat Kasar Silase}

Berdasarkan hasil penelitian, sifat fisik dan kandungan serat kasar silase batang pisang yang disuplementasi berbagai level hijauan kembang telang (Clitoria ternatea) disajikan pada Tabel 2. Sifat fisik yang dianalisi pada penelitian ini terdiri dari densitas, daya larut air, daya serap air dan kandungan serat kasar. 
Tabel 2. Sifat fisik dan serat kasar silase batang pisang yang disuplementasi berbagai level hijauan kembang telang (Clitoria ternatea).

\begin{tabular}{lccccc}
\hline \multirow{2}{*}{\multicolumn{1}{c}{ Parameter }} & \multicolumn{4}{c}{ Perlakuan $^{\mathbf{1})}$} & \multirow{2}{*}{ SEM $^{2)}$} \\
\cline { 2 - 4 } & $\mathbf{A}$ & $\mathbf{B}$ & $\mathbf{C}$ & $\mathbf{D}$ & \\
\hline Densitas (g/ml) & $0,14^{\mathrm{c} 3)}$ & $0,15^{\mathrm{b}}$ & $0,17^{\mathrm{a}}$ & $0,17^{\mathrm{a}}$ & 0,00 \\
Daya serap air (\%) & $232,26^{\mathrm{a}}$ & $201,71^{\mathrm{b}}$ & $191,66^{\mathrm{c}}$ & $167,78^{\mathrm{d}}$ & 9,20 \\
Daya larut air (\%) & $24,33^{\mathrm{c}}$ & $37,26^{\mathrm{b}}$ & $37,91^{\mathrm{b}}$ & $48,38^{\mathrm{a}}$ & 3,18 \\
Serat kasar (\%) & $21,58^{\mathrm{a}}$ & $21,22^{\mathrm{a}}$ & $21,14^{\mathrm{a}}$ & $19,00^{\mathrm{a}}$ & 1,91 \\
\hline
\end{tabular}

Keterangan :

${ }^{1)} \mathrm{A}: 65 \%$ batang pisang $+30 \%$ pollar $+5 \%$ (molasis + EM4 $)$

B: $55 \%$ batang pisang $+10 \%$ C. ternatea $+30 \%$ pollar $+5 \%$ (molasis + EM 4$)$

C: $45 \%$ batang pisang $+20 \%$ C. ternatea $+30 \%$ pollar $+5 \%$ (molasis + EM 4$)$

D: $35 \%$ batang pisang $+30 \%$ C. ternatea $+30 \%$ pollar $+5 \%$ (molasis + EM 4$)$

${ }^{2)}$ Standard Error Of The Treatment Means

${ }^{3}$ Nilai dengan huruf yang berbeda pada baris yang sama menujukan berbeda nyata $(\mathrm{P}<0,05)$

Analisis statistik densitas silase batang pisang disuplementasi berbagai level hijauan kembang telang Clitoria ternatea menujukkan hasil yang berbeda nyata $(\mathrm{P}<0,05)$. Densitas silase dengan penambahan 10\%, 20\% dan 30\% Clitoria ternatea (pada perlakuan B, C dan D) mendapatkan hasil masing-masing $0,15 \mathrm{~g} / \mathrm{ml}, 0,17 \mathrm{~g} / \mathrm{ml}$ dan $0,17 \mathrm{~g} / \mathrm{ml}$ dibandingkan dengan perlakuan A yang mempunyai densitas sebesar 0,14 g/ml. Penambahan 20\%-30\% Clitoria ternatea memberikan hasi tertinggi dengan meningkatkan nilai densitas sebesar $21,42 \%$ dari perlakuan A, 13,33\% dari perlakuan B.

Daya serap air adalah kemampuan ransum tersebut untuk menyerap air kembali setelah bahan atau ransum kering. Daya serap air silase batang pisang disuplementasi berbagai level hijauan kembang telang Clitoria ternatea menujukkan hasil yang berbeda nyata $(\mathrm{P}<0,05)$. Daya serap air silase batang pisang dengan penambahan 10\%, 20\% dan 30\% Clitoria ternatea mengalami penurunan (perlakuan B, C dan D) masing-masing 201,71\%, 191,66\% dan 167,78\% dibandingkan dengan perlakuan A mempunyai nilai daya serap air sebesar 232,26.

Daya serap air adalah kemampuan ransum tersebut untuk menyerap air kembali setelah bahan atau ransum kering. Daya serap air silase batang pisang disuplementasi berbagai level hijauan kembang telang Clitoria ternatea menujukkan hasil yang berbeda nyata $(\mathrm{P}<0,05)$. Daya serap air silase batang pisang dengan penambahan 10\%, 20\% dan 30\% Clitoria ternatea mengalami penurunan (perlakuan B, C dan D) masing-masing 201,71\%, 191,66\% dan 167,78\% dibandingkan dengan perlakuan A yang mempunyai nilai daya serap air sebesar 232,26\%.

Daya larut air silase batang pisang disuplementasi berbagai level hijauan kembang telang Clitoria ternatea menujukkan hasil yang berbeda nyata $(\mathrm{P}<0,05)$. Daya larut air silase batang pisang dengan penambahan 10\%, 20\% dan 30\% Clitoria ternatea mengalami 
peningkatan (perlakuan B, C dan D) masing-masing 37,26\%, 37,91\% dan 48,38\% dibandingkan dengan perlakuan A yang mempunyai nilai daya larut air sebesar 24,33\%. Penambahan $30 \%$ Clitoria ternatea menujukkan hasil tertinggi dengan meningkatnya daya larut air sebesar $1,98 \%$ dari perlakuan A, 1,29\% dari perlakuan B, dan 0,01\% dari perlakuan C.

Hasil penghitungan kandungan serat kasar silase batang pisang yang disupelemntasi berbagai level hijauan kembang telang (Clitoria ternatea) pada semua perlakuan berbeda tidak nyata ( $\mathrm{P}>0,05)$ dengan nilai masing-masing $21.58 \%$ (perlakuan A), $21.22 \%$ (perlakuan B), $21.14 \%$ (perlakuan C), $19.00 \%$ (perlakuan D) (Tabel 2).

\section{Sifat fisik silase}

Sifat fisik bahan penyusun ransum merupakan salah satu indikator untuk mengetahui kualitas bahan. Densitas ransum mengindikasikan keambaan. Semakin rendah densitas suatu pakan, maka makin amba pakan tersebut (Suryani et al., 2015). Silase batang pisang disuplementasi berbagai level hijauan kembang telang Clitoria ternatea menghasilkan densitas yang berbeda nyata $(\mathrm{P}<0,05)$. Data pada (Tabel 2) (ke arah perlakuan A) menujukkan persentase densitas terendah yaitu $0,14 \mathrm{~g} / \mathrm{ml}$. Rendahnya densitas pada perlakuan A berhubungan erat dengan kandungan serat kasar yang tinggi. Hal ini dibuktkan dari hasil penelitian serat kasar tertinggi pada perlakuan A (Tabel 2). Kandungan Serat kasar sangat berpengaruh terhadap densitas ransum, semakin tinggi kadar serat maka semakin rendah kerapatannya atau bahan tersebut semakin amba. Hijauan secara umum mempunyai nilai densitas yang rendah (Khalil, 1999). Pakan dengan tingkat keambaan yang lebih tinggi dapat menimbulkan regangan lebih besar dan memberikan sensasi kenyang lebih cepat pada saat dikonsumsi ternak, sehingga sifat amba tersebut dapat membatasi konsumsi pada ternak.

Daya serap air adalah kemampuan bahan ransum tersebut untuk menyerap air kembali setelah bahan/ransum kering. Silase batang pisang disuplementasi berbagai level hijauan kembang telang (Clitoria ternatea), dari data pada (Tabel 2) perlakuan A memeiliki daya serap air tertinggi sebesar $232.26 \%$, dan berbeda nyata $(\mathrm{P}<0,05)$ dengan perlakuan $\mathrm{B}, \mathrm{C}$ dan $\mathrm{D}$ (Tabel 2).Meningkatnya daya serap air pada perakuan A berhubungan erat dengan kandungan serat kasar. Hal ini dibuktikan dari hasil penelitian serat kasar tertinggi pada perlakuan A (21,58\%) (Tabel 2).Menurut Trowell et al., 1985 bahwa tingkat daya serap air tergantung pada jenis polisakarida komponen seratnya. Selulosa mempunyai kapasitas yang terbatas dalam menyerap air, sedangkan arabinoxylan mempunyai kapasitas penyerapan yang sangat besar. 
Menurut Siregar (2005) kelarutan suatu bahan pakan mempengaruhi kecepatan degeradasi bahan pakan tersebut. Daya larut air silase batang pisang disuplementasi berbagai level hijauan kembang telang Clitoria ternatea mendapatkan nilai tertinggi dengan rataan $48,38 \%$ (perlakuan D) dan secara statistik berbeda nyata $(\mathrm{P}<0,05)$ dari perlakuan $\mathrm{A}, \mathrm{B}$, dan C.

Tingginya daya larut air pada perlaukan D berhubungan erat dengan kecernaan bahan organik. Hal ini dibuktikan dari hasil penelitian kecernan bahan organik yang tertinggi pada perlakuan D (73,08\%) (Tabel 1). Bahan pakan yang mudah larut akan lebih mudah didegradasi didalam rumen. Bahan kering pakan dapat dibedakan menjadi dua fraksi terlarut dan fraksi tidak larut. Fraksi terlarut sebagian besar didegradasi di dalam rumen (Nocek, 1988). Fraksi bahan kering tidak terlarut dapet didegradasi pada kecepatan yang berbeda dan laju pengosongan didalam rumennya tergantung sifat fisik dan komposisi kimia dari partikel pakantersebut (Ramanzin et al., 1994).

Serat kasar yang terkandung pada silase batang pisang yang disuplementasi bebagai level hijauan kembang telang Clitoria ternateapada perlakuan A, B, C dan D secara statistik dinyatakan berbeda tidak nyata $(\mathrm{P}>0,05)$ dari semua perlakuan. Hal tersebut didukung oleh hasil penelitin daya serap air pada perlakuan A lebih tinggi dibandingkan dengan daya serap air pada perlakuan B, C dan D. Hal lain yang dapat mempengaruhi kadar serat kasar menurut Hartadi et al. (1993), yaitu adanya perbedaan umur tanaman, jenis lingkungan, dan pemupukan terhadap induk tanaman yang digunakan sebagai sampel.Diperkuat oleh AAK (2008), yang menyatakan semakin tua umur tanaman maka semakin tinggi serat kasarnya karena semakin banyak serabut yang diselubungi oleh lignin dan membuat tanaman menjadi keras, juga semakin rendah pula kecernaannya. Selain faktor tersebut, faktor lain seperti jenis tanaman dan komposisi tanaman mempengaruhi kadar serat kasar dalam pakan.

\section{SIMPULAN DAN SARAN}

\section{Simpulan}

Berdasarkan hasil penelitian ini dapat disimpulkan :

Silase batang pisang yang disuplementasi hijauan kembang telang (Clitoria ternatea)10\%, $20 \%$ dan 30\% dapat meningkatkan densitas, daya larut air dan menurunkan daya serap air , kandungan serat kasar. Penelitian ini belum bisa mendapatkan penambahan Clitoria ternatea optimal sehingga mampu menghasikan kualitas silase terbaik. 


\section{Saran}

Saran yang dapat diberikan dari penelitian ini yaitu perlu dilakukan penelitian lebih lanjut untuk mengetahui berapa persen penambahan Clitoria ternatea yang optimum pada silase batang pisang agar mendapatkan sifat fisik dan kandungan serat kasar terbaik.

\section{UCAPAN TERIMA KASIH}

Penulis mengucapkan terimakasih yang sebesar-besarnya kepada Rektor Universitas Udayana Prof. Dr. dr. Anak Agung Raka Sudewi, Sp.S (K), Dekan Fakultas Peternakan Dr. Ir. I Nyoman Tirta Ariana, MS, Koordinator Program Studi Sarjana Peternakan Dr. Ir. Ni Wayan Siti, M.Si, atas kesempatan dan fasilitas yang diberikan kepada penulis untuk mengikuti dan menyelesaikan pendidikan di Program Studi Sarjana Peternakan, Fakultas Peternakan, Universitas Udayana.

\section{DAFTAR PUSTAKA}

AAK. 2008. Teknik Bercocok Tanam Jagung. Kanisius. Jogyakarta.

Advena, D. 2014. Fermentasi batang pisang menggunakan probiotik dan lama inkubasi berbeda terhadap perubahan kandungan bahan kering, protein kasar dan serat kasar. Jurnal. Program Studi Peternakan Fakultas Pertanian Universitas Tamansiswa. Padang.

Association of Analytical Communities, 1992. Methods of the Assosiation of Official Analitical Chemists. Published by the AOAC. Washington DC.

Dewi, O., N. N. Suryani, dan I M. Mudita. 2020., Kecernaan Bahan Kering dan Bahan Organik Secara In-Vitro dari Silase Kombinasi Batang Pisang dengan Kembang Telang (Clitoria ternatea). Peternakan Tropika. Vol. 8, (1): 60 - 73.

Dhalika, T., A. Budiman, B. Ayuningsih dan Mansyur. 2011. Nilai nutrisi batang pisang dari produk bioproses (ensilage) sebagai ransum lengkap. Jurnal Ilmu Ternak 11(1): 17-23.

Hasrida. 2011. Pengaruh Dosis Urea dalam Amoniasi Batang Pisang terhadap Degradasi Bahan Kering, Bahan Organik dan Protein Kasar Secara InVitro. Skripsi. Fakultas Peternakan Universitas Andalas. Padang.

Hartadi, H., S. Reksohadiprodjo, S. Lebdosoekojo dan A.D. Tillman. 1993. Tabel Komposisi Pakan untuk Indonesia. Gadjah Mada University Press, Yogyakarta

Kalamani A, S. M. Gomez. 2001. Genetic variability in Clitoria spp. Ann AgricRes. 22:243-245.

Khalil. 1999. Pengaruh kandungan air dan ukuran partikel terhadap perubahan perilaku fisik bahan pakan lokal: kerapatan tumpukan, kerapatan pemadatan tumpukan dan berat jenis. Med. Peternakan. Vol. 22, (1): 1-11. 
Noek, J. E. 1988. In situ and other methods to estimate ruminal protein and energy digestibility. A Review J. Dairy Sci. 71: 20-51.

Ramanzin, M., L. Bailoni, and G. Bittante. 1994. Solubility, waterholding capacity, and specific gravity of different concentrates. J. Dairy Sci. 77:774-781

Santi, R. K., D. Fatmasari, S. D. Widyawati, dan W. P. S. Suprayogi. 2012. Kualitas dan nilai kecernaan In Vitro silase batang pisang (Musa paradisiaca) dengan penambahan beberapa akselerator. Tropical Animal Husbandry 1(1):15-23

Suarna, I. W. 2005. Kembang telang (Clitoria ternatea) tanaman pakan dan penutup tanah. Dalam: Lokakarya Nasional Tanaman Pakan Ternak. 16 September 2005. Puslitbang Peternakan Bogor (Indonesia).

Suryani, N. N, I. G. Mahardika, S. Putra, dan N. Sujaya. 2015. Sifat fisik dan kecernaan ransum sapi bali yang mengandung hijauan beragam. Jurnal Peternakan Indonesia. Vol.17(1): 39-45.

Trowell, H., D. Burkitt \& K. Heaton. 1985. Dietary Fiber, Fiber Depleted Food and Disease. Academic Press, London. 